\title{
O049: Can the search-and-isolate strategy for controlling the spread of highly resistant bacteria (HRB) be mitigated?
}

\author{
G Birgand ', I Lolom', L Armand-Lefevre ${ }^{2}$, S Belorgey ${ }^{3}$, E Ruppé $^{2}$, A Andremont ${ }^{2}$, J-C Lucet $^{3^{*}}$ \\ From 2nd International Conference on Prevention and Infection Control (ICPIC 2013) \\ Geneva, Switzerland. 25-28 June 2013
}

\section{Introduction}

French recommendations for controlling HRB spread (carbapenemase producing enterobacteriacae [CPE] and vancomycin resistant enterococci [VRE]) advocate an aggressive search-and-isolate strategy.

\section{Objectives}

We describe the experience of a teaching hospital, adjusting control measures to the epidemiological risk analysis (EpiRA).

\section{Methods}

From 01/2009 to 12/2012, 31 episodes (13 VRE, $16 \mathrm{CPE}$, $2 \mathrm{VRE}+\mathrm{CPE}$ [13 OXA-48, 3 KPC, 2 NDM1]) have been identified. An EpiRA was performed : time from admission to $\mathrm{HRB}+$, number of cases, compliance with standard (SP) and contact precautions (CP), workload (of the index case (IC), of the ward), nurse-to-patient (Pt) ratio, antibiotic use. Measures were adapted to the EpiR assessment, from strict CP for a single case to cohorting with dedicated staff for carriers, contact Pts and newly admitted Pts (3 distinct areas) when secondary cases $(\mathrm{SeC})$ were identified. Initial and weekly screening of contact Pts was systematically performed.

\section{Results}

Pts were initially hospitalised in intensive care $(\mathrm{n}=8)$, medical $(n=18)$ or surgical units $(n=5)$. Length of stay varied from 3 days to 13 month (median, 20 days). 14 IC were identified within $48 \mathrm{~h}$. following hospital admission. Strict CP were started for all IC, transfers and new admissions were stopped in 9/31 episodes, and after the

Bichat, Claude Bernard Hospital, Paris, France

Full list of author information is available at the end of the article occurrence of $\mathrm{SeC}$ for 5 others. The nursing staff was reinforced in 6 episodes and carriers were cared by dedicated staff in 3 other episodes, one with 3 distinct areas. $\mathrm{SeC}$ were identified in 9/31 episodes (7 VRE and 2 $\mathrm{CPE}$ ), with 1 to $5 \mathrm{SeC} /$ episode (18 SeC). 4 VRE IC identified 7 to 60 days after hospital admission generated 1 to $5 \mathrm{SeC}$ ( $\mathrm{n}=12$, 3/episode); 3 VRE episodes with strict $\mathrm{CP}$ started at hospital admission generated $4 \mathrm{SeC}(1.3 /$ episode). $2 \mathrm{SeC}$ were identified in $2 \mathrm{CPE}$ episodes, 1 after 31 days and 1 after 72 days.

\section{Conclusion}

This experience is the largest reported in France. SeC were more frequent in VRE (16 in 15 episodes) than in CPE (2 in 18 episodes). Our data suggest that control measures could be adapted according to EpiRA, if several conditions are gathered. However, SeC occurred around Pts under strict $\mathrm{CP}$, highlighting that this strategy should be used prudently.

\section{Disclosure of interest}

None declared.

\section{Author details}

${ }^{1}$ Infection control unit, Claude Bernard Hospital, Paris, France. ${ }^{2}$ Bacteriology unit, Claude Bernard Hospital, Paris, France. ${ }^{3}$ Bichat, Claude Bernard Hospital, Paris, France.

Published: 20 June 2013

doi:10.1186/2047-2994-2-S1-049

Cite this article as: Birgand et al:: O049: Can the search-and-isolate strategy for controlling the spread of highly resistant bacteria (HRB) be mitigated? Antimicrobial Resistance and Infection Control 2013 2(Suppl 1): 049 .

(c) 2013 Birgand et al; licensee BioMed Central Ltd. This is an Open Access article distributed under the terms of the Creative Commons 